$\xi=-1$

\title{
Critical studies on bond strengths of masonry units
}

\author{
B.P. Nandurkar ${ }^{1}$, Dr. A. M. Pande ${ }^{2}$ \\ ${ }^{1}$ Assistant Professor, Civil Engineering Department, Yeshwantrao Chavan College of Engineering College, \\ Wanadongari, Nagpur, India \\ ${ }^{2}$ Director, R\&D, \& Professor Civil Engg. Department,YeshwantraoChavan College of Engineering College, \\ Wanadongari, Nagpur, India
}

\begin{abstract}
Performance of masonry is normally attributed to compressive strength of individual units, water absorption of individual units, strength of masonry mortar and the bond between mortar and individual units. Many researches in the past have contributed towards the bond strength and relevance of compressive strength of mortar in achieving good bonds. However, the quality of bricks available in India significantly vary from region the region. Thus, a need is felt in understanding bond strength of masonry. In this paper three types of mortars(total nine combinations), two types of bricks (red clay brick and fly ash brick) are considered, tests such as compressive strength, water absorption of the bricks, compressive strength of various mortar combinations, flexure bond strength and shear bond strength are presented. Failure patterns of the masonry units are also discussed. Results of the two tests show noticeable variation in bond strengths, however the shear bond strength has significant relationship with the compressive strength of mortar. The research outcome also points towards using bricks in saturated condition for achieving adequate performance.
\end{abstract}

Keywords: Mortar; Brick Prism; Bond Strength.

\section{Introduction}

Brick masonry plays a major role in the field of building construction. Masonry unit is constructed with building blocks (bricks) units with mortar. Performance of masonry significantly depends on the characteristics of masonry units, type of mortar used and the bonding between them.

Many failure theories have been proposed for brick masonry in compression. When the bond strength between the brick and mortar is poor, the prism failure is also accompanied by a failure of the brick-mortar bond. Bond strength is dependent on many interrelated factors that can directly affect bond development. This bond strength mainly depends on unit surface absorption, pore structure, mortar composition, mortar water retentively, curing cycle, unit surface texture and workmanship. The mortar quality and surface absorption criteria of the masonry unit are the most important parameters in developing good bond and bond strength. Various combinations of masonry mortars are detailed in two distinct Indian standards IS: 2250 and IS: 1905 . The IS: 2250 has detailed 28 days compressive strength for various grades of mortar combinations. For performance of estimation of masonry mortar, the code has recommended compressive strength test, only. Though IS: 1905 recommends flexural strength and bond strength requirement of masonry units but test setup and testing procedure is not detailed in any of the code.

For best quality bricks, maximum compressive strength recommended is between $7.5 \mathrm{~N} / \mathrm{mm}^{2}$ to $10 \mathrm{~N} / \mathrm{mm}^{2}$. However, in practice normally cement sand mixes are used resulting in higher 28 days strength. Many investigations have been carried out in the past to stipulate the nature of brick masonry and their essential properties under different conditions. But, there are no appropriate results available or typical provisions that could meet the necessities of the engineers.
The purpose of this experimental study was, to find the true match for brick, mortar and masonry to obtain the good bondage between brick and mortar.

\section{Earlier studies on bond strength of brick masonry}

G. Sarangapani et al. (2005) [1] studied that, the bond strength is better when blocks are partially saturated blocks than dry or fully saturated blocks. They concluded increase in bond strength, while keeping the mortar composition and strength constant, leads to an increase in compressive strength for masonry prisms and the compressive strength of masonry increases with the increase in bond strength. Ronald Lumantarna et al. (2014) [2], examined the importance of sufficient masonry mortar joint-bond strength when a structure is subjected to in-plane and out-of-plane loads. They concluded that, the measured cohesion increased in accordance with increasing average mortar compressive strength and the mortar bed joint cohesion is better characterized using the mortar compressive strength than using the masonry compressive strength. Other observations are shear failure within the mortar joints and their bed joint shear strengths were influenced by the mortar properties instead of the brick/mortar bond characteristics. Md. Toihidul Islam et al. (2014) [3], recommended that adding fibers to hydraulic lime mortars promises an increase in the overall resilience of the stone-mortar bond. Daniel V. Oliveira (2011) [4], studied the experimental performance of FRP strengthened clay masonry prisms under tensile and shear loading. The results show that the tensile strength of the brick and mortar controls the tensile strength of the FRP-masonry interface. Within this context, it seems reasonable to use low strength bonding agent in the strengthening of (low strength) masonry constructions. Adelaja Israel Osofero et al. (2014) [5], experimentally showed that the 
titanium-lime bond is characterized by low bond strength. They investigated the bond behavior of titanium bars with lime-based mortars, emphasizing the effect of applied surface treatments. Increase in surface tension and surface roughness results in the formation of stronger bond, which allows for increase in strength and durability. James Colville, et al. (1999) [6], describes an investigation of improving the bond strength of masonry mortars through the use of polymer additives, so that more efficient use of unreinforced masonry may be realized. Results indicate that the use of additives polymer and super plasticizer increase the tensile bond strength of masonry more when used together. Hemant B Kaushik et.al. (2007) [7], proposed the stress-strain curves for masonry that can be used in the analysis and design procedures. The model requires only the compressive strengths of brick and sand mortar as input data. It was observed that for the strong and stiff bricks and mortar of lesser but comparable strength and stiffness, the stress-strain curves of masonry do not necessarily fall in between those of bricks and mortar. Simple relations are suggested to estimate the modulus of elasticity of bricks, mortar, and masonry as 300,200 , and 550 times their compressive strengths, respectively. Sawko and Rouf (1984) [8] presented an analytical method for finding axial and bending stiffness of masonry walls by taking parabolic variation of stress-strain curves for masonry in compression based on past experimental studies. Bennett et al. (1997) [9] showed that the masonry prism strength has a linear relationship with the compressive strength of bricks, and that the prism strength for loading perpendicular to the bed joint can be conservatively estimated as three-tenths of the brick compressive strength. This method of estimating the masonry prism strength may overestimate the prism strength because it does not give any weightage to the strength of mortar used in prisms. Also, a linear relationship was proposed between elastic modulus and prism strength of masonry. Costigan, A. et al. (2009) [10], investigated that the failure mode of masonry beams depends on the bond strength, a weak mortar leads failure at the mortar block interface whereas a strong bond lead to break through the block. Venkatarama, R. B. V (2008) $)^{11}$, showed that for masonry prisms with blocks stronger than the mortar, the compressive strength was found to be less sensitive to bond strength. Fouad M. Khala $(2005)^{12}$, presented a test method for determination of flexural bond strength by bending. The results showed that the proposed new specimen and test procedure are capable of determining the flexural bond strength easily and accurately. Jie Li et al. (2016) [13], developed a computational method to predict the strength for unreinforced masonry walls subject to one-way horizontal bending considering unit-to-unit spatial variability of the material properties of mortar joints and bricks. The results were validated from a database of available experimental results on masonry and were found good.

Scope of this study:

In this study, the flexural bond strength and shear bond strength of masonry using two types of locally available bricks (red clay brick and fly ash brick) in dry and partially saturated condition and three types mortars 1:3,1:4 and 1:5, with partial replacement of cement with fly ash and rice husk ash (total nine combinations) have been considered. Flexural bond strength is determined using a modified bond wrench test, and shear bond strength is determined with a test on a brick triplet.

\section{Experimental details}

Two types of bricks are used in the experimental work, red clay bricks and fly ash bricks. To understand the bond strength and flexural strength, brick prism was casted with different mortar proportions of 1:3, 1:4 and 1:5.

Locally available burnt clay bricks and fly ash bricks were used in the experimental work. Compressive strength and water absorption tests were performed on brick units to get information about the quality of bricks. The results are summarized in table [1]. Wa- ter absorption tests were performed on fly ash bricks and clay bricks as per IS 3495 (1992).

Ordinary Portland cement of 43 grade was used for the experimental work. Natural river sand used for the experimentation was having specific gravity, fineness modulus and bulking of sand 2.66, 3.33 and 21.49 respectively. Fly ash and rice husk ash was also used in the experimental work. The replacement of cement with fly ash and rice hush was $25 \%$ and $20 \%$ respectively. For compressive strength test on mortar, $70.6 \times 70.6 \times 70.6 \mathrm{~mm}$ mortar cubes were casted and tested after 7 days and 28 days of curing. Water absorption test was conducted after 28 days of curing on mortar cube.

Table 1: Test Result of Clay Brick and Fly Ash Brick

\begin{tabular}{|c|c|c|c|}
\hline $\begin{array}{l}\mathrm{S} . \\
\mathrm{N}\end{array}$ & $\begin{array}{l}\text { Type of Bricks } \\
\text { used }\end{array}$ & $\begin{array}{l}\text { Compressive strength } \\
\left(\mathrm{N} / \mathrm{mm}^{2}\right)\end{array}$ & $\begin{array}{l}\text { Water absorption } \\
(\%)\end{array}$ \\
\hline 1. & Clay brick & 4.74 & 17.90 \\
\hline 2. & Fly ash brick & 13.63 & 12.47 \\
\hline
\end{tabular}

\subsection{Construction of brick prism}

Two types of brick prism were constructed. Three-layer brick prism and four-layer brick prism were constructed for the experimental work. Construction of brick prism was done on a horizontal platform. One brick was placed on a horizontal platform having its frog on its upper side and then $12 \mathrm{~mm}$ mortar was placed on the brick by filling the frog fully. Other bricks were placed in similar manner to construct three layer and four-layer brick prisms. Dry bricks were used for construction of dry brick prism and wet bricks were used for construction of wet prism in the research work. Wet bricks are wetted for 15 minutes before the construction of wet prism.

\subsection{Mixture proportions and sample preparation}

The mortar mix proportion of 1:3,1:4 and 1:5 were used in this work. Cement was replaced by FA and RHA by $20 \%$ and $25 \%$ respectively. For each proportion three mixes were prepared. For proportion 1:3, 1:4 and 1:5, the water cement ratios were determined from workability criteria point of view and were $0.5,0.55$ and 0.6 respectively.

\subsection{Experimental Testing}

\subsubsection{Compressive strength test on mortar mixes}

For compressive strength test, cube specimens of dimensions 70.6, $70.6,70.6 \mathrm{~mm}$ were casted. After 24 hours, the specimens were demolded and transferred to curing tank wherein they were cured for 7, 28 days. These cubes were tested on compression testing machine. The failure load was noted in the compression testing machine. For each mix three cubes were casted and after testing average values are reported.

\subsubsection{Water absorption on mortar mixes}

The amount of water absorbed depends on water tightness of the mixes. A mortar mix of water absorption below $10 \%$ are said to be good mortar mixes. The cubes for water absorption test were casted as per ASTM C642 and ASTM C1403-15 and the tests were carried out after 28 days of curing. For the water absorption test, the cubes were first kept in an oven $105 \pm 5^{\circ} \mathrm{C}$ for 24 hours weighted (dry weight, Wd). Then they were immersed in water for further 24 hours and weighted again (wet weight, $\mathrm{Ww}$ ). The water absorption was then calculated by using the following formula.

water absorption $(\%)=\frac{\mathrm{w}_{\mathrm{w}}-\mathrm{w}_{\mathrm{d}}}{\mathrm{w}_{\mathrm{d}}} * 100$

Test results of compressive strength test and water absorption tests are presented in table 2 . 
Table 2: Test Result of Mortar Mixes

\begin{tabular}{|c|c|c|c|c|c|}
\hline $\begin{array}{l}\text { S. } \\
\mathrm{N}\end{array}$ & $\begin{array}{l}\text { Mortar } \\
\operatorname{mix}\end{array}$ & w/c & $\begin{array}{l}\text { Compre } \\
\left(\mathrm{N} / \mathrm{mm}^{2}\right. \\
7 \text { Days }\end{array}$ & $\begin{array}{l}\text { Strength } \\
28 \text { Days }\end{array}$ & $\begin{array}{l}\text { Water Absorption } \\
(\%) \\
28 \text { Days }\end{array}$ \\
\hline 1 & MM13 & 0.5 & 8.66 & 13.83 & 5.87 \\
\hline 2 & $\begin{array}{l}\text { MM13 } \\
\text { FA }\end{array}$ & 0.5 & 10.26 & 12.76 & 8.71 \\
\hline 3 & $\begin{array}{l}\text { MM13 } \\
\text { RHA }\end{array}$ & 0.5 & 9.34 & 11.43 & 7.89 \\
\hline 4 & MM14 & 0.55 & 5.62 & 10.20 & 8.83 \\
\hline 5 & $\begin{array}{l}\text { MM14 } \\
\text { FA }\end{array}$ & 0.55 & 11.40 & 18.94 & 9.04 \\
\hline 6 & $\begin{array}{l}\text { MM14 } \\
\text { RHA }\end{array}$ & 0.55 & 5.97 & 9.44 & 13.42 \\
\hline 7 & MM15 & 0.6 & 5.15 & 8.70 & 8.70 \\
\hline 8 & $\begin{array}{l}\text { MM15 } \\
\text { FA }\end{array}$ & 0.6 & 5.17 & 8.84 & 10.13 \\
\hline 9 & $\begin{array}{l}\text { MM15 } \\
\text { RHA }\end{array}$ & 0.6 & 3.63 & 4.76 & 10.89 \\
\hline
\end{tabular}

3.3.3. Flexural bond strength on four-layer brick prism: modified bond wrench test

Flexural bond strength of the brick masonry was determined by testing four brick bonded prism stacks. Flexural bond strength of the masonry prisms was determined using bond wrench test. The bond wrench test as specified by the ASTM C-1072. Figure 1 shows the details of the modified bond wrench test setup. The prism was supported on a rigid bottom. The bottommost brick of the prism was fully clamped. The load was applied to the topmost brick of the prism through a pulley arrangement. This load causes a moment in the prism, which will further cause a flexure failure between the masonry unit and the mortar. The bending stress developed in the prism was calculated by using the following formula,

Bending stress $(F)=\frac{M * Y}{I}$

$\mathrm{F}=$ Bending stress $\left(\mathrm{N} / \mathrm{mm}^{2}\right)$

$\mathrm{M}=$ Bending moment $(\mathrm{N}-\mathrm{mm})$

$\mathrm{Y}=$ Distance measured from top of the prism up to the prism

$\mathrm{Y}=\operatorname{break}(\mathrm{mm})$

$\mathrm{I}=$ Moment of inertia $\left(\mathrm{mm}^{4}\right)$
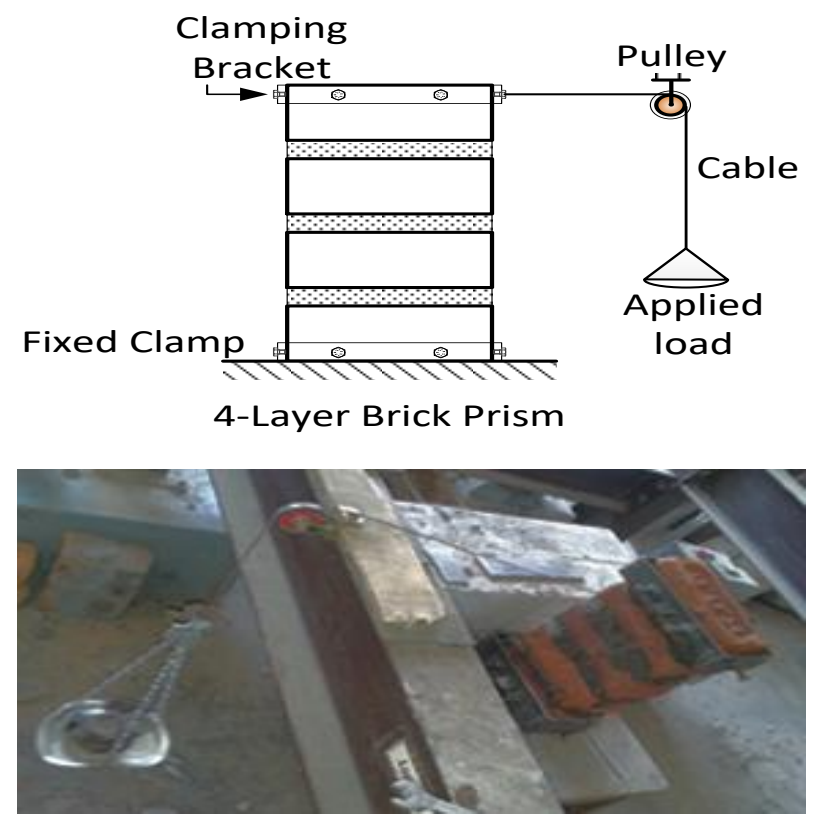

Fig. 1: Flexural Bond Strength Test Setup Schematic Sketch and Actual Testing.

\subsubsection{Shear bond strength joints on three-layer brick prism}

A brick triplet specimen was used to find shear bond strength of the brick mortar joints. The test setup is shown in Figure 2. It is clear from the figure that the horizontal movement of the top and bottom bricks was restrained and the middle brick was free to move horizontally. Horizontal load was applied gradually using hydraulic jack till the bond between brick and mortar joint failed. The shear bond stress developed was calculated by using the following formula,

Shear bond stress $=\frac{\mathrm{P}}{2 \mathrm{~A}}$

$\mathrm{P} \quad=\quad$ Applied load $(\mathrm{N})$

A $\quad=\quad$ Cross sectional area $\left(\mathrm{mm}^{2}\right)$
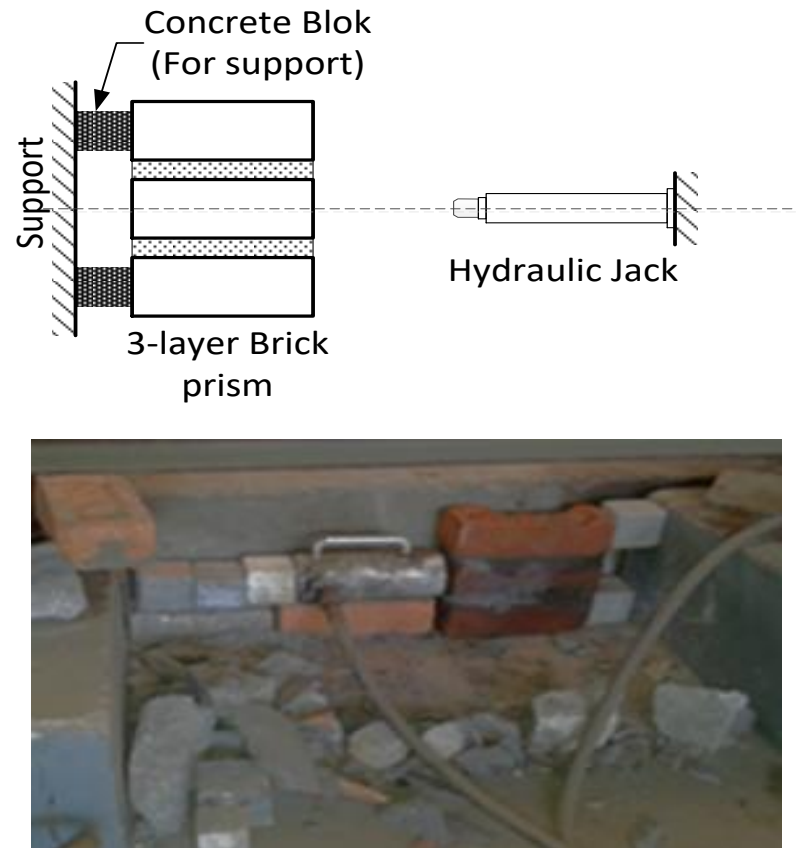

Fig. 2: Shear Bond Strength Test Setup Schematic Sketch and Actual Testing.

Test results of flexural bond test and shear bond test on both the types of bricks are presented in table 3 and 4, specific results for bricks in partially saturated conditions are re-presented in graphical form in figures 7,8 and 9. In the figures, RCB means Red Clay Brick and FAB means Fly Ash Brick

\subsubsection{Mode of failure of brick prism}

A brief observation was made on the failure obtained from the testing of brick prism. Bond failure might occur due to weak bondage between mortar and bricks and or due to poor mortar strength. Two types of modes of failure were observed, failure of bricks in flexural and bond failure. Bond failure and failure of bricks in flexure occurs due to bond failure of brick interface, bond failure in mortar joint and combination of both failure of brick interface and mortar joint. The types of failures observed are shown in figure 3 to 6 . Following are the type of failure observed in flexural and shear bond test.

Type I: Bond failure: There are two types of bond failure observed, Type I (a): Bond failure at brick-mortar interface and Type I (b): Bond failure within mortar joint, Type II: Failure of brick, Type III: A combination of Types I and II 


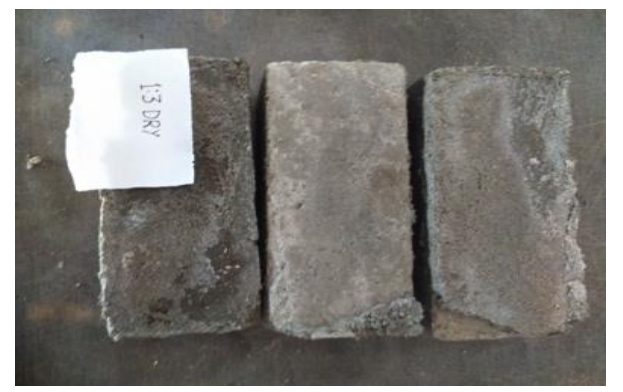

Fig. 3: Type I (A): Bond Failure at Brick-Mortar Interface.

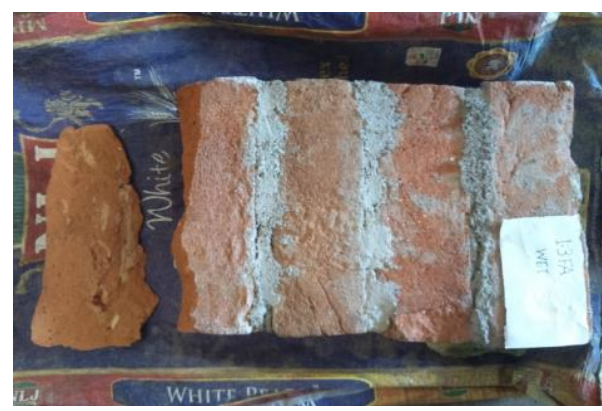

Fig. 5: Type II: Failure of Brick in Flexure.

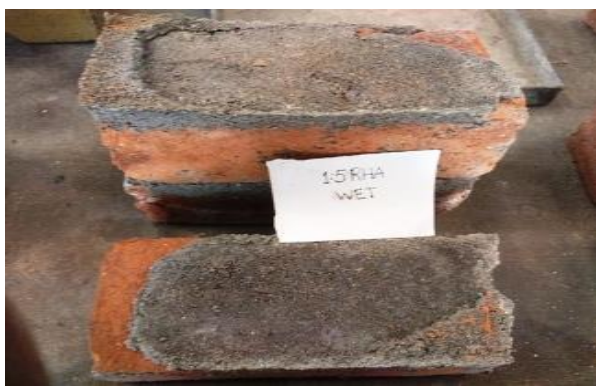

Fig. 4: Type I (B): Bond Failure within Mortar Joint.

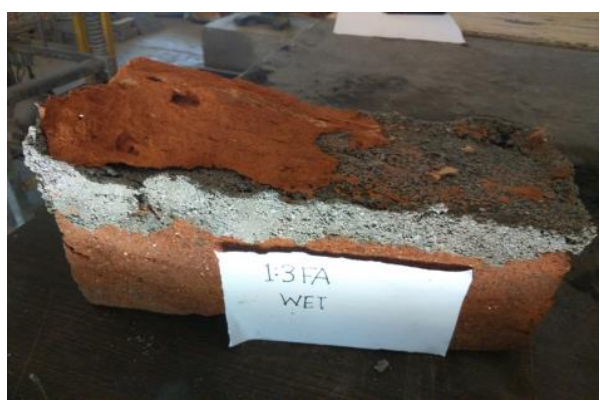

Fig. 6: Type III: A Combination of Types I and II.

Table 3: Flexural Bond Strengths of Prisms and Mode of Failure

\begin{tabular}{|c|c|c|c|c|c|c|c|}
\hline \multirow{3}{*}{ S. N } & \multirow{3}{*}{ Mortar mix } & \multicolumn{3}{|c|}{ Red Clay Brick } & \multicolumn{3}{|c|}{ Fly Ash Bricks } \\
\hline & & \multicolumn{2}{|c|}{ Flexural bond strengths $\left(\mathrm{N} / \mathrm{mm}^{2}\right)$} & \multirow{2}{*}{ Mode of Failure } & \multicolumn{2}{|c|}{ Flexural bond strengths $\left(\mathrm{N} / \mathrm{mm}^{2}\right)$} & \multirow{2}{*}{ Mode of Failure } \\
\hline & & Dry Brick & Saturated Brick & & Dry Brick & Saturated Brick & \\
\hline 1 & MM13 & 0.92 & 1.77 & \multirow{2}{*}{ Type I (b)- Dry, Type II Wet } & 0.53 & 1.3 & \multirow{3}{*}{$\sum^{\infty}$} \\
\hline 2 & MM13 FA & 0.66 & 2.3 & & 0.49 & 0.98 & \\
\hline 3 & MM13 RHA & 0.38 & 1.86 & Type II- Dry, Type I(a) Wet & 0.77 & 1.19 & \\
\hline 4 & MM14 & 0.99 & 0.59 & Type I (b)- Dry \& Wet & 0.73 & 2.06 & $\infty$ \\
\hline 5 & MM14 FA & 0.51 & 1.65 & Type I (b)- Dry, Type II Wet & 0.82 & 1.29 & $\hat{5}$ \\
\hline 6 & MM14 RHA & 0.37 & 2.09 & Type I (a)- Dry \& Wet & 0.85 & 1.33 & $\stackrel{1}{\approx}$ \\
\hline 7 & MM15 & 0.27 & 0.74 & \multirow{2}{*}{ Type I (b)- Dry \& Wet } & 0.56 & 1.74 & $\underbrace{\mathbb{E}}$ \\
\hline 8 & MM15 FA & 0.4 & 1.11 & & 0.42 & 1.26 & $\overline{2}$ \\
\hline 9 & MM15 RHA & 0.54 & 1.37 & Type I (a)- Dry \& Wet & 0.21 & 0.87 & 空 \\
\hline
\end{tabular}

Table 4: Shear Bond Strength of Triplet Prisms

\begin{tabular}{|c|c|c|c|c|c|c|c|}
\hline \multirow{3}{*}{ S. N } & \multirow{3}{*}{ Mortar Mix } & \multirow{2}{*}{\multicolumn{2}{|c|}{$\begin{array}{l}\text { Red Clay Brick } \\
\text { Shear bond strengths }\left(\mathrm{N} / \mathrm{mm}^{2}\right)\end{array}$}} & \multirow{3}{*}{ Mode of Failure } & \multirow{2}{*}{\multicolumn{2}{|c|}{$\begin{array}{l}\text { Fly Ash Bricks } \\
\text { Shear bond strengths }\left(\mathrm{N} / \mathrm{mm}^{2}\right)\end{array}$}} & \multirow{3}{*}{$\begin{array}{l}\text { Mode of } \\
\text { Failure }\end{array}$} \\
\hline & & & & & & & \\
\hline & & Dry Brick & Saturated Brick & & Dry Brick & Saturated Brick & \\
\hline 1 & MM13 & 0.296 & 0.593 & \multirow{3}{*}{ Type I (a)- Dry, Type III Wet } & 0.078 & 0.412 & \\
\hline 2 & MM13 FA & 0.198 & 0.543 & & 0.071 & 0.293 & 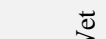 \\
\hline 3 & MM13 RHA & 0.237 & 0.445 & & 0.233 & 0.356 & 3 \\
\hline 4 & MM14 & 0.257 & 0.395 & \multirow{2}{*}{ Type I (a)- Dry, Type I(b) Wet } & 0.351 & 1.04 & $\infty$ \\
\hline 5 & MM14 FA & 0.296 & 0.346 & & 0.39 & 0.621 & $\hat{\theta}$ \\
\hline 6 & MM14 RHA & 0.099 & 0.375 & \multirow[t]{2}{*}{ Type I (a)- Dry \& Wet } & 0.268 & 0.638 & $\stackrel{1}{2}$ \\
\hline 7 & MM15 & 0.148 & 0.247 & & 0.272 & 0.837 & $\underbrace{\mathbb{E}}$ \\
\hline 8 & MM15 FA & 0.099 & 0.296 & \multirow[t]{2}{*}{ Type I (a)- Dry \& Wet } & 0.192 & 0.598 & 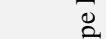 \\
\hline 9 & MM15 RHA & 0.099 & 0.198 & & 0.096 & 0.27 & E \\
\hline
\end{tabular}

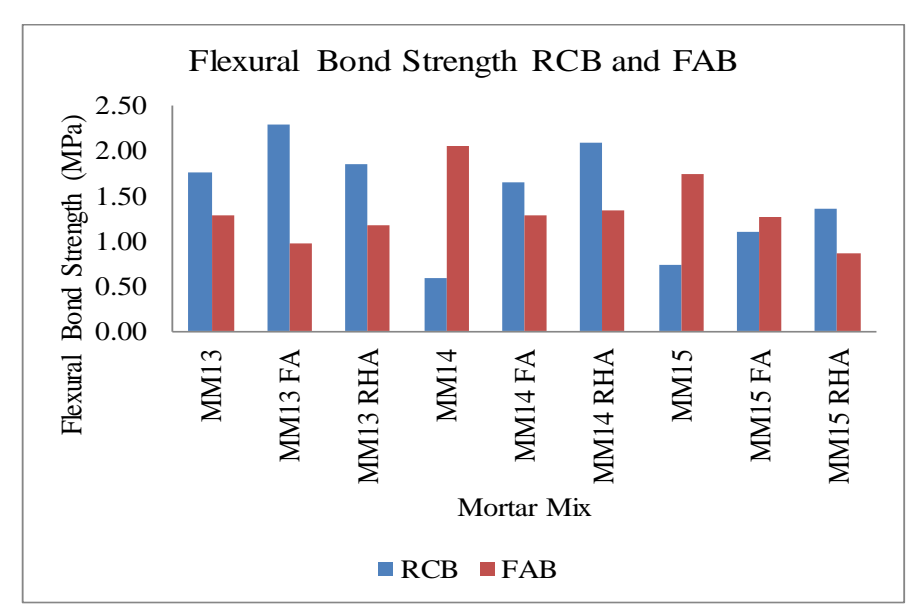

Fig. 7: Comparison of Flexural Bond Strength of Red Clay Bricks and Fly Ash Bricks under Saturated Condition. 


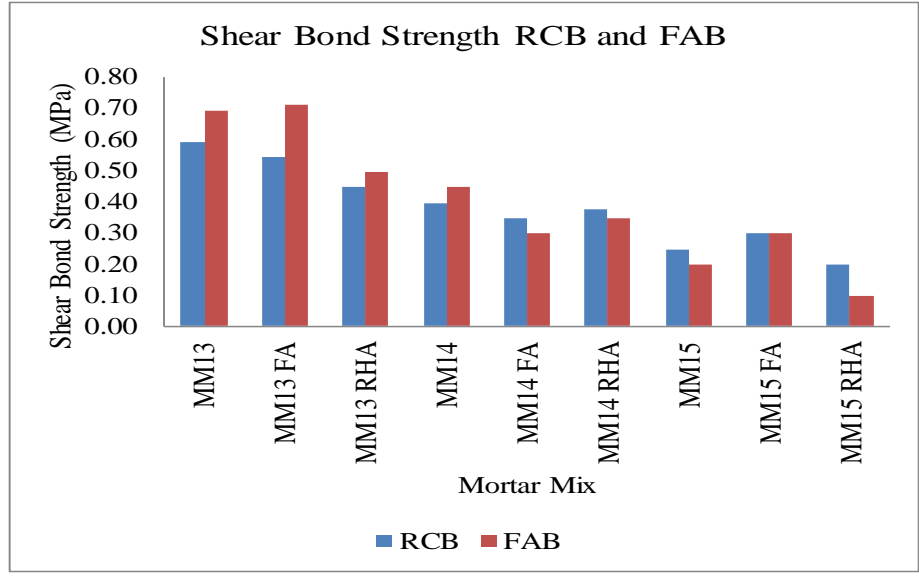

Fig. 8: Comparison of Shear Bond Strength of Red Clay Brick and Fly Ash Bricks under Saturated Condition.

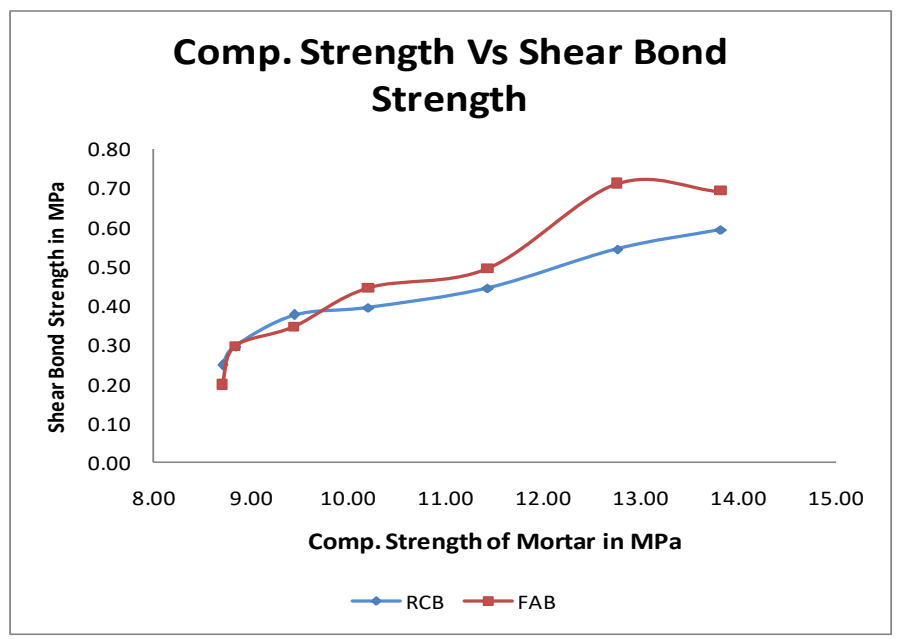

Fig. 9: Compressive Strength vs. Shear Bond Strength.

\section{Discussions}

In case of fly ash brick, the failure has normally occurred at the interface of bricks and mortar indicating the true failure of bond for all types of mortars when the bricks were placed in dry and partially saturated conditions. In case of red clay bricks, especially in richer mixes either the bricks have failed or the bond within mortar joint has failed. This indicates that the compressive strength of individual bricks also plays important role in the flexure bond strength. However, in case of leaner mixes (1:5) the failure was normally seen at brick mortar interface.

Shear bond strength: In case of fly ash brick the failure was at interface of brick and mortar when the fly ash bricks were placed at dry and wet condition. In case of red clay bricks the influence of various grades of mortar is different and detailed below:.

a) In richer mixes, when the dry bricks were used failure was at interface indicating the absorption of water by dry bricks is resulting in loss of strength at interface, while when the bricks were placed in saturated condition the failure observed was the combination of failure at interface, failure within mortar joint and failure of bricks.

b) In the leaner mixes like 1:5, it was typically observed that the failure was at brick mortar interface, indicating the weakness of mortar bond strength.

Typically, in richer mixes the fly ash bricks have better performance. In leaner mixes especially in mixes containing rice husk ash, the shear bond strength is on lower side. Eliminating the extreme case of mortar strength typically the shear bond strength increases with increase in compressive strength of mortar. This is indicated in figure 9. The shear bond strength in case of fly ash bricks is marginally higher than red clay bricks.
Flexural bond strength: In richer mixes flexural bond strength of red clay brick is found to be more than fly ash brick indicating that higher mortar strength and frog in the red clay brick is responsible for achieving higher strength, while in leaner mixes both have similar strengths.

In case of mortar mixes containing rice husk ash the strengths are on lower side indicating that the hygroscopic nature of rice husk ash is hampering bond strength.

\section{Concluding remarks}

To understand the behavior of masonry units, especially in relevance to the bond between masonry mortar and bricks the two approaches adopted Flexure bond strength and Shear bond strength give significantly different results. As bond strengths are dependent on the compressive strength of mortar, water absorption of individual units, provision of frog in red clay brick and the use of supplementary cementitious material in mortar.

The performance of richer and leaner mixes in red clay bricks and fly ash bricks are different. The shear bond strength is related to compressive strength of mortars and can be regarded as a better alternative. No direct relevance of flexural bond strength with compressive strength of mortars is observed.

The conclusions are based on the brick samples collected from Nagpur region of India, so they cannot be directly correlated to other bricks; however, these results signify the relevance of shear bond strength.

Further research work incorporating bricks from different sources is expected to give new dimension in this regard. 


\section{Acknowledgements}

The authors are thankful to Yeshwantrao Chavan College of Engineering authorities for permitting the testing of samples in the material laboratory.

\section{References}

[1] G. Sarangapani; B. V. Venkatarama Reddy; and K. S. Jagadish "Brick-Mortar Bond and Masonry Compressive Strength" Journal of Materials in Civil Engineering, Vol. 17, No. 2, April 1, 2005. (C)ASCE, ISSN 0899-1561/2005/2-229-237/

[2] Ronald Lumantarna; David T. Biggs, Dist.M.ASCE; and Jason M. Ingham, "Compressive, Flexural Bond, and Shear Bond Strengths of In Situ New Zealand Unreinforced Clay Brick Masonry Constructed Using Lime Mortar between the 1880s and 1940s" Journal of Materials in Civil Engineering, Vol. 26, No. 4, April 1, 2014. (C) ASCE, ISSN 0899-1561/2014/4-559-566/.

[3] Md. Toihidul Islam and VivekBindiganavile, Ph.D. "Dynamic Fracture Toughness of Sandstone Masonry Beams Bound with Fiber-Reinforced Mortars" Journal of Materials in Civil Engineering, Vol. 26, No. 1, January 1, 2014. C ASCE, ISSN 0899-1561/2014/1 125-133\%.

[4] Daniel V. Oliveira, Ph.D.; Ismael Basilio, Ph.D.; and Paulo B. Lourenço, Ph.D "Experimental Bond Behavior of FRP Sheets Glued on Brick Masonry" Journal of Composites for Construction,Vol. 15, No. 1, February 1, 2011. (CASCE, ISSN 1090-0268/2011/1-32-41.

[5] Adelaja Israel Osofero, Ph.D.; Marco Corradi, Ph.D.; and Antonio Borri "Experimental Study of Bond Strength between TitaniumBar and Lime-Based Mortar "Journal of Materials in Civil Engineering, (C) ASCE, ISSN 0899-1561/04014182(10)/.

[6] James Colville, Made M. Made, and M. Miltenberger "TENSILE BOND STRENGTH OF POLYMER MODIFIED MORTAR" Journal of Materials in Civil Engineering, Vol. 11,No. 1, February, 1999.@ASCE, ISSN 0899-1561/99/0001-0001-0005/.

[7] Hemant B. Kaushik, Durgesh C. Rai, and Sudhir K. Jain, "Stress Strain Characteristics of Clay Brick Masonry under Uniaxial Compression", 728 / Journal of materials in civil engineering (C) ASCE / September 2007, https://doi.org/10.1061/(ASCE)08991561(2007)19:9(728).

[8] Sawko, F., and Rouf, M. A. (1984). "On the stiffness properties of masonry.” Proc. Inst. Civ. Eng., Part 2. Res. Theory, 77, 1-12.

[9] Bennett, R. M., Boyd, K. A., and Flanagan, R. D. (1997). "Compressive properties of structural clay tile prisms." J. Struct. Eng., 123(7), 920-926. $\quad$ https://doi.org/10.1061/(ASCE)07339445(1997)123:7(920)

[10] Costigan, A., and Pavia, S. (2009). "Compressive, flexural and bondstrength of brick/lime mortar masonry." Proc. PROHITEC-09, 1, Taylorand Francis Group, London, 1609-1615.

[11] Venkatarama, R. B. V., and Vyas, U. (2008). "Influence of shear bondstrength on the compressive strength and stress-strain characteristicsof masonry." Mater. Struct. 41(10), 1697-1712. https://doi.org/10.1617/s11527-008-9358-x.

[12] Fouad M. Khalaf1, (2005). "New Test for Determination of Masonry Tensile Bond Strength"Journal of Materials in Civil Engineering, 2005, 17(6): 725-732. https://doi.org/10.1061/(ASCE)08991561(2005)17:6(725).

[13] Jie Li; Mark G. Stewart; Mark J. Masia; and Stephen J. Lawrence, "Spatial Correlation of Material Properties and Structural Strength of Masonry in Horizontal Bending", Journal of Structural Engineering, 2016, 142(11): 04016112. https://doi.org/10.1061/(ASCE)ST.1943-541X.0001488.

[14] IS: 2250-1981, "Code of practice for preparation and use of masonry mortars", BIS, New Delhi.

[15] IS: 1905-1987, "Code of practice for structural use of unreinforced masonry", BIS, New Delhi.

[16] ASTM C1072, "Standard Test Methods for Measurement of Masonry Flexural Bond Strength".

[17] ASTM C642, "Standard Test Method for Density, Absorption, and Voids in Hardened Concrete".

[18] ASTM C1403, "Standard Test Method for Rate of Water Absorption of Masonry Mortars". 